\title{
How effective are River Basin Management Plans in reaching the nutrient load reduction targets?
}

\author{
Mikołaj Piniewski $@$, Sirkka Tattari, Jari Koskiaho, \\ Olle Olsson, Faruk Djodjic, Marek Giełczewski, Paweł Marcinkowski, \\ Marta Księżniak, Tomasz Okruszko
}

Received: 17 June 2020/Revised: 13 August 2020/ Accepted: 1 September 2020/Published online: 27 September 2020

\begin{abstract}
Riverine nutrient loads are among the major causes of eutrophication of the Baltic Sea. This study applied the Soil \& Water Assessment Tool (SWAT) in three catchments flowing to the Baltic Sea, namely Vantaanjoki (Finland), Fyrisån (Sweden), and Słupia (Poland), to simulate the effectiveness of nutrient control measures included in the EU's Water Framework Directive River Basin Management Plans (RBMPs). Moreover, we identified similar, coastal, middle-sized catchments to which conclusions from this study could be applicable. The first modelling scenario based on extrapolation of the existing trends affected the modelled nutrient loads by less than $5 \%$. In the second scenario, measures included in RBMPs showed variable effectiveness, ranging from negligible for Stupia to $28 \%$ total $\mathrm{P}$ load reduction in Vantaanjoki. Adding spatially targeted measures to RBMPs (third scenario) would considerably improve their effectiveness in all three catchments for both total $\mathrm{N}$ and $\mathrm{P}$, suggesting a need to adopt targeting more widely in the Baltic Sea countries.
\end{abstract}

Keywords Baltic Sea · Best Management Practices · Nutrient load · River Basin Management Plans . SWAT model $\cdot$ Targeting of measures

\section{INTRODUCTION}

Aquatic eutrophication caused by excessive loads of nutrients transported by rivers to the Baltic Sea remains the primary environmental issue despite investments aimed at

Electronic supplementary material The online version of this article (https://doi.org/10.1007/s13280-020-01393-x) contains supplementary material, which is available to authorized users. the reduction of pollution from both point and diffuse sources within its drainage basin. The Baltic Sea is particularly vulnerable to waterborne nutrient loads as a result of the following factors: (1) large size of the basin compared to the sea area; (2) long freshwater renewal time; and (3) limited water exchange with the North Sea.

In 1974, the Helsinki Convention established an organisation called the Helsinki Commission (HELCOM). All the Baltic Sea coastal states are parties to HELCOM and the Helsinki Convention, together with the European Union (EU). A program for regular data collection has been set up within HELCOM, and official hot-spot "problem areas" have been identified. Until the 1980 's, the share of point sources, primarily from wastewater treatment plants, was high in many countries. Therefore, the focus was on reducing such sources. While point sources have been successfully addressed, diffused sources of nutrient pollution related to e.g. large-scale animal farm production and other agricultural activities and are yet to be resolved.

In 2007, the Baltic Sea Action Plan (BSAP) was adopted by HELCOM's contracting parties (i.e. countries and the European Union). BSAP is an ambitious program aimed at restoring good ecological status of the Baltic marine environment by 2021. It relies on the latest scientific knowledge and innovative management approaches to strategic policy throughout the Baltic Sea region (BSR). The BSAP is not static-it is regularly updated in annual ministerial meetings.

HELCOM member states are also obliged to implement the EU's Water Framework Directive's (WFD) regional River Basin Management Plans (RBMPs). The 4th planning period, ending in 2021, is currently underway. The objective of RBMPs to achieve good status of surface waters is similar to that of BSAP, but in addition to coastal areas it covers inland waters and groundwaters. Moreover, 
RBMPs define measures needed to achieve this target. Meeting this objective, as well as that of BSAP, however, has proven difficult, and not all water bodies and coastal waters of BSR will reach good status for the period of 2021-2027 (e.g. Schumacher 2012; Knuuttila et al. 2017; Bohman 2018).

HELCOM has set specific targets for reducing nutrient loads. In 2007, original preliminary reductions of phosphorus $(\mathrm{P})$ and nitrogen $(\mathrm{N})$ were stipulated, compared to the input in the reference period of 1997-2003 (HELCOM 2007). In 2013, the figures were revised based on a new and more complete dataset. The new Maximum Allowable Inputs (MAIs) were set at different levels, and Country Allocated Reduction Targets (CARTs) were established for different sea areas and countries of the Baltic Sea (HELCOM 2013; Table 1).

Over the recent decades, hydrological and water quality modelling has become an important tool to improve the understanding of the effects of various types of pollution sources on nutrient loads at different spatial scales. This is particularly apparent in BSR due to many past and ongoing projects aimed at quantifying the effectiveness of both already implemented and suggested measures. Models are used for estimating nutrient loads (Hesse et al. 2015; Huttunen et al. 2015; Thodsen et al. 2017; Olesen et al. 2019) and identifying hot spots with high nutrient losses (Thodsen et al. 2015; Andersen et al. 2016; Djodjic and Markensten 2019). They are also used for assessing the effectiveness of measures such as buffer zones (Piniewski et al. 2015), constructed wetlands (Arheimer and Pers 2017), and catch crops (Konrad et al. 2014). In the conditions of intensifying climate change, models are also increasingly frequently used for the assessment of its interactions with land use, management practices, and effects on water quality. It should be emphasised that this type of research usually focuses on longer time horizons reaching 2050 or even 2100 (Piniewski et al. 2014;
Huttunen et al. 2015; Olesen et al. 2019). In addition to climate change, socio-economic aspects have been considered with more attention in recent studies predicting trends in catchment management and assessing nutrient loads (Pastuszak et al. 2014; Huttunen et al. 2015; Olesen et al. 2019).

The objectives of this paper are as follows: (1) Estimation of factors affecting nutrient loads for the purpose of modelling their changes in a 15-year perspective in three medium-sized catchments flowing into the Baltic Sea; (2) Evaluation of the effectiveness of catchment-specific nutrient load control measures included in the existing RBMPs in a 15-year perspective; (3) Evaluation of how spatial targeting of measures could enhance the effectiveness of RBMPs in three case study catchments.

\section{MATERIALS AND METHODS}

\section{Case study catchments}

Three medium-sized coastal catchments situated in Finland, Sweden and Poland were selected for focused modelling studies and comparisons.

The Vantaanjoki $(101 \mathrm{~km})$ in southern Finland drains a $1688 \mathrm{~km}^{2}$ catchment, and flows into the Gulf of Finland (Fig. 1). The climate is characteristic of the boreal zone and belongs to the $D f b$ (warm-summer humid continental) class according to the Köppen-Geiger system (Beck et al. 2018). Mean precipitation is $660 \mathrm{~mm}^{-1} \mathrm{yr}^{-1}$ and mean water flow is $11.5 \mathrm{~m}^{3} \mathrm{~s}^{-1}$, ranging between 0.7 and $125 \mathrm{~m}^{3} \mathrm{~s}^{-1}$. The elevation ranges between 0 and $150 \mathrm{~m}$ a.s.l. The highest parts and reliefs of the catchment occur in the north and are mostly covered by forest. Agricultural land and clay soils are predominant in the middle and southern part of the catchment which is flat or slightly hilly. Land use includes forests (53\%), agriculture (25\%), and urban areas (18\%),

Table 1 Country-specific N and P mean annual loads as well as CART and RBMP reduction targets

\begin{tabular}{|c|c|c|c|c|c|}
\hline \multicolumn{2}{|l|}{ Country } & \multirow{2}{*}{$\begin{array}{l}\text { PLC ('06; '14) annual load } \\
{\left[\mathrm{t}^{\mathrm{a}} \text { year }^{-1}\right]}\end{array}$} & \multirow{2}{*}{$\begin{array}{l}\mathrm{CART}^{\mathrm{b}} \text { target reduction } \\
{\left[\mathrm{t} \mathrm{year}^{-1}\right]}\end{array}$} & \multirow{2}{*}{$\begin{array}{l}\mathrm{RBMP}^{\mathrm{c}} \text { target reduction } \\
{\left[\mathrm{t}_{\text {year }}{ }^{-1}\right]}\end{array}$} & \multirow{2}{*}{$\begin{array}{l}\text { CART reduction } \\
{[\%]}\end{array}$} \\
\hline Finland & $\mathrm{N}$ & & & & \\
\hline & $\mathrm{P}$ & 3585 & 356 & 440 & 10 \\
\hline \multirow[t]{2}{*}{ Poland } & $\mathrm{N}$ & 188499 & 43610 & na & 23.1 \\
\hline & $\mathrm{P}$ & 12214 & 7480 & na & 61 \\
\hline \multirow[t]{2}{*}{ Sweden } & $\mathrm{N}$ & 120323 & 9240 & 13720 & 7.7 \\
\hline & $\mathrm{P}$ & 3463 & 530 & 1167 & 16 \\
\hline
\end{tabular}

${ }^{a}$ Pollution Load Compilation, estimation based on PLC reports regarding years 2006 and 2014

${ }^{\mathrm{b}}$ Country Allocated Reduction Targets

${ }^{\mathrm{c}}$ River Basin Management Plans 

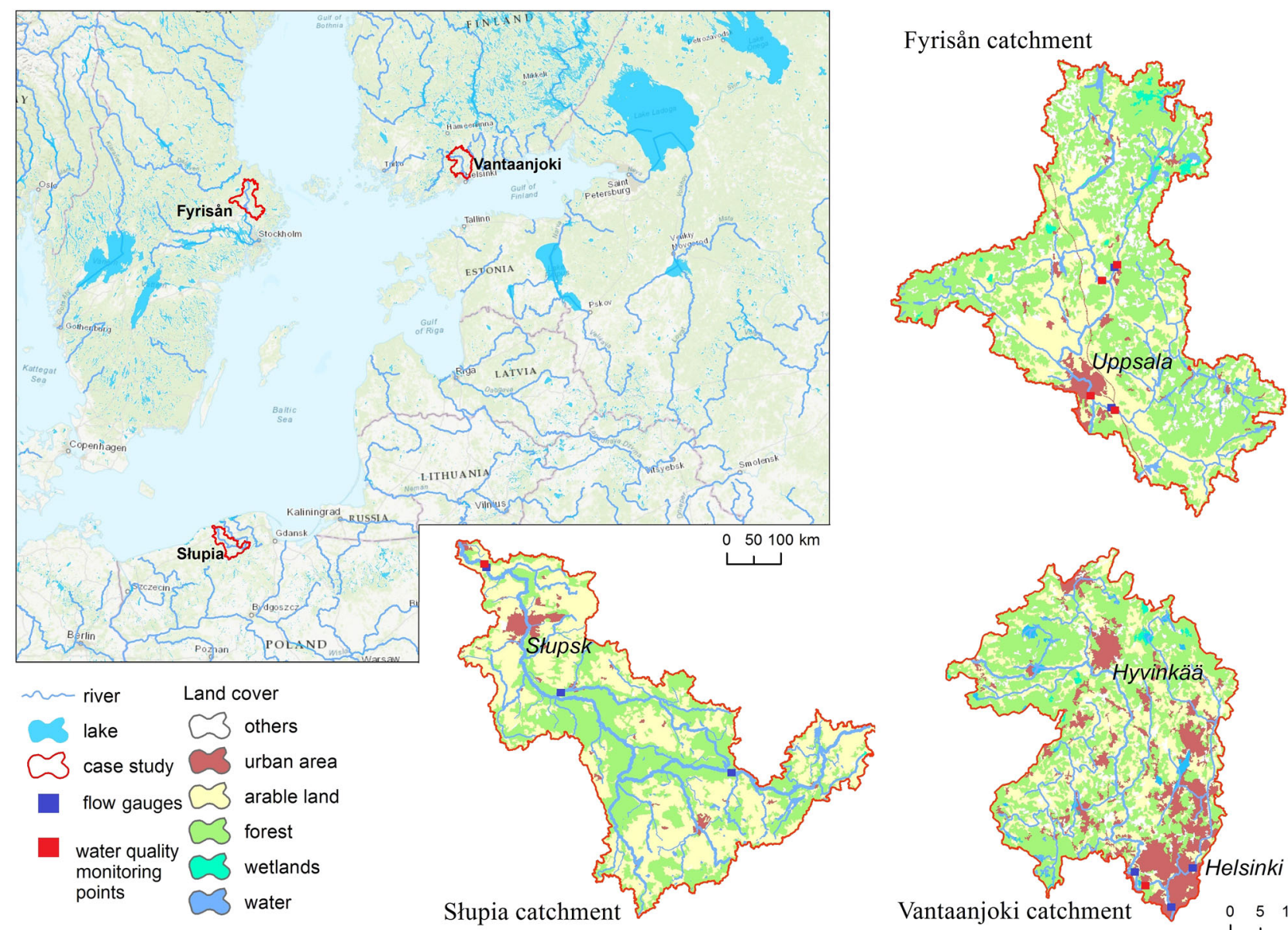

$\bigwedge^{N}$

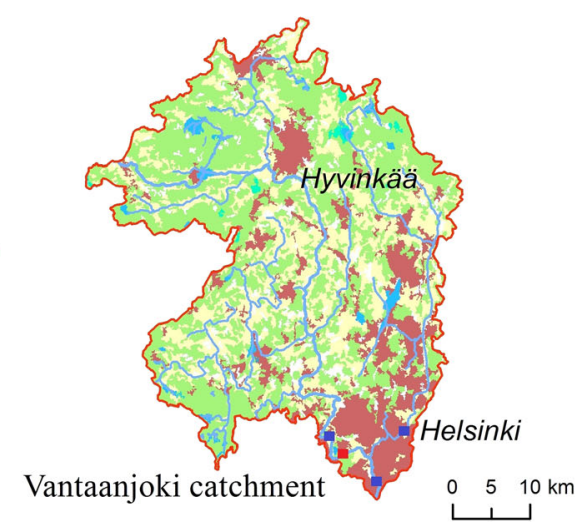

Fig. 1 Location of case study catchments

and water covers $2 \%$ of its area. The city of Helsinki with approximately 655000 inhabitants is located in the southeastern corner of the catchment.

The Fyrisån catchment $\left(1982 \mathrm{~km}^{2}\right)$ is located in the southeastern part of Sweden. The approximately $80 \mathrm{~km}$ long Fyrisån is part of the wider Norrström drainage basin, and discharges into Lake Mälaren which has its outlet through Stockholm into the Baltic Sea. The climate and vegetation are characteristic of the boreal zone like in the Vantaanjoki catchment, with climate also classified as $D f b$. Mean annual precipitation is approximately $550-600 \mathrm{~mm} \mathrm{year}^{-1}$. Land use in the catchment is distributed between forests $(60 \%)$, agriculture (32\%), wetlands (4\%), lakes (2\%), and urban areas $(2 \%)$. Soils in the catchment are primarily glacial tills on forest land, whereas clay soils dominate in agricultural regions. Altitudes range from 1 to $117 \mathrm{~m}$ a.s. 1 , and mean water flow in the Fyrisån is approximately $13 \mathrm{~m}^{3} \mathrm{~s}^{-1}$, ranging between 1 and $140 \mathrm{~m}^{3} \mathrm{~s}^{-1}$. The urban area is dominated by the city of Uppsala (population of approximately 170 000). The Fyrisån flows through the city just before reaching Lake Mälaren.
The Słupia catchment $\left(1623 \mathrm{~km}^{2}\right)$ is a coastal river basin in northern Poland. It drains into the southern Baltic Sea through the $138 \mathrm{~km}$ long Słupia River (Fig. 1). Climatically it belongs to $D f b$ class (warm-summer humid continental). Mean annual precipitation is $850 \mathrm{~mm} \mathrm{a}^{-1}$ and mean (2000-2016) water flow at the outlet of the catchment is $17 \mathrm{~m}^{3} \mathrm{~s}^{-1}$, ranging from 8.4 to $53 \mathrm{~m}^{3} \mathrm{~s}^{-1}$. The relief is diverse and characterised by a mosaic of several morainic uplands and sandy outwash plains dissected with a network of eroding and tunnel valleys. The altitude ranges between 0 and $267 \mathrm{~m}$ a.s.l., with the highest parts in the south-east of the basin. The most typical soil types are sands and loamy sand. The middle part of the catchment is mostly covered by forest, with a considerable share of urban areas, while agricultural land is predominant in the southern and northern parts. Agricultural land and forest represent $49 \%$ and $44 \%$ of the catchment, respectively. Urban areas have been growing in size over recent years, and currently constitute approximately $5 \%$, in majority covered by the city of Słupsk (approximately, 90000 inhabitants). 


\section{Identification of similar coastal catchments}

Water quality modelling efforts often focus on small areas, predominantly on single catchments due to both systematic (catchment as the basic hydrological unit) and practical (data availability, time and labour input) reasons. On the other hand, regional studies are of great importance, especially in the case of evaluation of impacts related to policy actions (e.g. WFD or BSAP). Our study, covering three middle-sized coastal catchments in three different countries of the BSR, exemplifies such a situation. As in many other hydrological 'case studies', this raises the question: to which other geographical areas could conclusions of this study be transferred? One possible way of addressing this question is through identification of catchments that are 'similar' to those investigated in the present study. Catchment similarity can be analysed from different perspectives. Here we are mainly interested in factors affecting nutrient load generation process.

It should be emphasised that catchments geographically neighbouring on the three analysed catchments do not necessarily have to share similar behaviours and responses (He et al. 2011). This study adopted a catchment regionalisation perspective where three selected catchments serve as 'donors', and the goal is to derive a set of 'target' catchments based on certain similarity principles (McIntyre et al. 2005; Zhang and Chiew 2009). More specifically, we used the hydrological distance approach proposed by $\mathrm{He}$ et al. (2011). It had been previously applied for another purpose (model parameter transfer problem) in two large river basins in BSR, namely the Vistula and Odra by Piniewski et al. (2017). The method employs a set of physiographic characteristics to evaluate the physical similarity of catchments. In this study, the method was applied in a consistent manner, but separately for each country.

The analysis was based on four groups of catchment characteristics related to land use (percent of different types: urban, agriculture, forest, wetlands, and waters), soils (percent of gravel, sand, silt, and clay in topsoil and in subsoil, and percent of peat areas), topography (slope of agricultural land), and size. This set of characteristics is believed to describe the underlying physical processes leading to nutrient load generation from the landscape. We intentionally ignored other potential characteristics that are related to human activities, e.g. fertilizer rates, wastewater treatment plant (WWTP) loads and dams.

All characteristics were calculated by means of the available GIS data for a group of coastal catchments in each country. We excluded catchments smaller than $300 \mathrm{~km}^{2}$ and larger than three-fold area of a given catchment. We also focused on catchments draining directly to the Baltic Proper, Gulf of Finland, and Bothnian Bay.
Climate was also taken into account by restricting the analysis to the $D f b$ zone, represented by all the catchments.

\section{SWAT model}

SWAT is a process-based, semi-distributed, continuoustime model that simulates the movement of water, sediment, $\mathrm{N}$ and $\mathrm{P}$ compounds within a catchment with a daily time step (Arnold et al. 1998). SWAT requires specific information on weather, soil, topography, vegetation, and land management, and computes the processes associated with water and sediment movement, plant growth, nutrient cycling, etc. based on such input data. SWAT uses basic spatial units called HRUs (hydrological response units) combining land use, soil, and slope within each sub-basin. The land-phase total suspended solid (TSS) and nutrient transport components, namely land erosion, nutrient fluxes and water balance, are computed separately for each HRU, aggregated at the sub-basin level, and then routed through the river network to the main outlet.

A SWAT model application was developed for each catchment. The sources of data used in modelling of the three case study catchments are presented in Table S1 of the Electronic Supplementary Material (ESM). Despite some obvious differences in terms of data sources between countries, an attempt was made to develop SWAT models for each catchment in a consistent way. The catchments were delineated into 93, 51, and 76 sub-catchments, and 1708, 1760 and 1764 HRUs for Fyrisån, Vantaanjoki, and Słupia, respectively. Rigorous model calibration and validation for river discharge, sediment, and nutrient loads was performed for each case (see Piniewski et al. 2019 for the Vantaanjoki case). Basic characteristics of flow gauges and water quality monitoring points can be found in Table S2 (cf. Figure 1 for their location). Automatic calibration and uncertainty analysis with SWAT-CUP software (SUFI-2 programme) were carried out (Abbaspour et al. 2004). Kling-Gupta efficiency (KGE) number was adopted as the goodness-of-fit criterion (Gupta et al. 2009). However, we considered other important model performance measures such as $\mathrm{R}^{2}$ and percent bias (PBIAS) (cf. Table S6). The calibrated/validated model applications were used as 'Baseline' scenarios.

\section{Trends in the catchments}

Collecting historical data were necessary for the analysis of current trends in the catchments' characteristics influencing water quality, and for the development of a model scenario that would include near-future developments in the catchments. The historical data were collected in 6 thematic areas: land use, agricultural area, livestock, fertiliser use, WWTP loads, and demography (Table S2). We collected 
data at a spatial scale feasible for a given feature, ranging from catchments to administrative units such as municipalities, counties, provinces, or even countries. Although we used the data sources that to our knowledge are the best for each case, we acknowledge the fact that differences in spatial levels of aggregation may have an impact on trend analysis, particularly in the case when data for a larger unit (e.g. a province in Poland or a production area in Sweden) are taken to estimate trends in a catchment that occupies its small fraction. Annual data for the longest available subperiod within the period 2000-2018 were acquired for all characteristics except land use. For land use, we used the Corine Land Cover data base for years 2000, 2006, 2012, and 2018.

\section{Assessment of RBMPs}

RBMPs are the basic planning documents required by WFD and the national Water Law for designing and enforcing actions aimed at the improvement or maintenance of good status of water bodies. The formal way of RBMP design and implementation is the discretion of Water Authority of a given Member State, but in all cases, the design of the Programme of Measures (PoM) requires the identification of the gap between the water's current status and good status, followed by planning of a possibly cost-effective combination of measures.

Due to the differences in the RBMP development process in different countries, we collected the related country-specific information in Table $\mathrm{S} 3$. We selected measures feasible for SWAT modelling from each RBMP. In short, the Finnish RBMP contains primarily agri-environmental measures: buffer zones, constructed wetlands, winter time vegetation cover of fields, and perennial grass cultivation. The Swedish plans include the same first two measures as the Finnish ones, followed by reduced $\mathrm{P}$ leakage from spreading of manure, and stormwater ponds in urban areas. In contrast, the Polish RBMP only includes measures related to the wastewater sector: WWTPs modernization/ extension, constructing new on-site WWTPs, and constructing new septic tanks.

\section{Targeting of measures}

WFD implementation has triggered a shift towards a targeted approach to the placement of measures that could significantly improve their environmental efficiency and cost efficiency (Doody et al., 2012). As revealed by our analysis of RBMPs, they often specify the quantity or spatial extent of particular measures (e.g.
$\mathrm{X}$ constructed wetlands, $\mathrm{Y}$ ha of buffer zones), but rarely their precise location within the river basin. In Finland, targeting of measures is recommended in the current programming period, but in practice it has remained rather limited.

From the modelling perspective, the placement of measures is one of the key decisions in scenario design. In the case of no evidence or suggestions regarding the placement of measures, they can be placed randomly. Another approach is spatial targeting of measures at certain areas within the model setup (in the case of SWAT they would be sub-basins or HRUs). Here, we have applied simple common-sense rules towards targeting, summarised as follows:

- winter time vegetation cover and buffer zones are targeted at agricultural HRUs with highest slopes;

- constructed wetlands are primarily targeted at subbasins with a high proportion of agricultural land;

- stormwater ponds are targeted at sub-basins with a high proportion of urban land;

\section{Implementation of scenarios in SWAT}

This study involved the development of a consistent set of four scenarios per catchment: (i) Baseline, describing the current status of nutrient loads (years 2002-2016) based on calibrated models, and three scenarios looking into the mid-term ( $\sim 15$ year) development of nutrient loads: (ii) Business-As-Usual (BAU), extrapolating historical trends in key variables affecting water quality into the future, (iii) $\mathrm{BAU}+\mathrm{RBMP}$, adding currently implemented and recommended measures to achieve the WFD goals for pollution reduction to BAU scenario, and (iv) $\mathrm{BAU}+\mathrm{RBMP}+\operatorname{targ}$, either adding the same measures that were already planned under RBMPs, but targeting them at potential nutrient load generation hot spots, as described in "Targeting of measuresWFD" section (Vantaanjoki and Fyrisån), or adding new measures (from outside RBMPs) and also targeting them at hot spot areas (Słupia).

Table 2 shows how particular factors of BAU scenario and measures included in BAU + RBMP and BAU + RBMP + targ scenarios were implemented in SWAT. For BAU scenario, the situation was straightforward-all three factors, i.e. land use change, fertilisation change and change in load from WWTPs, were analysed in each catchment. Measures included in RBMPs, however, differed between catchments, and so did the implementation of these measures in SWAT. 


\section{RESULTS}

\section{Identified similar coastal catchments}

The application of the hydrological distance approach described in "Identification of similar coastal catchments" section resulted in the selection of 28 Swedish coastal catchments covering an area of $32000 \mathrm{~km}^{2}$ similar to Fyrisån, 12 Finnish coastal catchments covering an area of $8200 \mathrm{~km}^{2}$ similar to Vantaanjoki, and six Polish coastal catchments covering an area of $11000 \mathrm{~km}^{2}$ similar to Słupia (Fig. 2). A high number of similar catchments derived for Sweden resulted from fairly uniform values of catchment characteristics calculated for Swedish catchments. In the case of Finland, the situation was different due to two reasons: high fraction of urban land cover in Vantaanjoki, and high fraction of peat soils present in northern Finland. Only nine catchments in Poland met the initial criteria for the analysis, primarily due to much shorter coastline.

The total area of which the three selected catchments are representative is almost ten times greater than the total area of the three catchments themselves.

\section{Model calibration and validation}

Calibration and validation for mean flow $\left(\mathrm{m}^{3} \mathrm{~s}^{-1}\right)$ as well as sediment $\left(\mathrm{t} \mathrm{day}^{-1}\right)$ and nutrient $\left(\mathrm{kg} \mathrm{day}^{-1}\right)$ loads were performed for each of the study catchments. For flow, daily mean values were used in all three catchments. In terms of sediment and nutrient loads, in Vantaanjoki and Fyrisån daily mean values were used, and in Słupia monthly mean values. In Vantaanjoki, the daily load dataset was based on continuous (hourly) water quality and daily flow datasets (see Piniewski et al. 2019), and in Fyrisån we computed daily loads only for days when concentration data were available (typically once per month) and used them as the observational data set for calibration.

KGE values for flow shown in Table 3 can be generally regarded as high (in addition, the values of $\mathrm{R}^{2}$ and percent bias, PBIAS, are provided in Table S2). Therefore, we can rely on SWAT applications to accurately simulate the hydrology of the catchments. The best results for nutrients were achieved for Vantaanjoki (for both calibration and validation periods) (see Piniewski et al. 2019). This is also reflected in similar temporal dynamics between the observed and simulated values during the calibration

Table 2 Implementation of scenario factors and measures in SWAT for three studied catchments

\begin{tabular}{|c|c|c|c|}
\hline Factor/measure & SWAT implementation & Scenario & Catchment \\
\hline Land cover change & $\begin{array}{l}\text { Parameters controlling hru size in.hru } \\
\text { files and urban.dat file }\end{array}$ & BAU & $\begin{array}{l}\text { Fyrisån, Vantaanjoki, } \\
\text { Słupia }\end{array}$ \\
\hline Fertilization change & $\begin{array}{l}\text { Mineral fertilizer or manure application } \\
\text { rates in.mgt files }\end{array}$ & $\mathrm{BAU}$ & $\begin{array}{l}\text { Fyrisån, Vantaanjoki, } \\
\text { Słupia }\end{array}$ \\
\hline Change in load from WWTPs & $\begin{array}{l}\text { Nutrient load values in point source files } \\
\text { representing WWTPs }\end{array}$ & BAU & $\begin{array}{l}\text { Fyrisån, Vantaanjoki, } \\
\text { Słupia }\end{array}$ \\
\hline Buffer zones & Vegetative filter strip function in.ops files & $\begin{array}{l}\mathrm{BAU}+\mathrm{RBMP} \\
\mathrm{BAU}+\mathrm{RBMP}+\operatorname{targ}\end{array}$ & Fyrisån, Vantaanjoki, \\
\hline Constructed wetlands & Wetland parameters in.pnd files & $\begin{array}{l}\mathrm{BAU}+\mathrm{RBMP}, \\
\mathrm{BAU}+\mathrm{RBMP}+\operatorname{targ}\end{array}$ & $\begin{array}{l}\text { Fyrisån, Vantaanjoki, } \\
\text { Słupia }\end{array}$ \\
\hline Wintertime vegetation cover of fields & Management practices in.mgt files & $\begin{array}{l}\mathrm{BAU}+\mathrm{RBMP} \\
\mathrm{BAU}+\mathrm{RBMP}+\operatorname{targ}\end{array}$ & $\begin{array}{l}\text { Fyrisån, Vantaanjoki, } \\
\text { Słupia }\end{array}$ \\
\hline Perennial grass cultivation & Management practices in.mgt files & $\mathrm{BAU}+\mathrm{RBMP}$ & Vantaanjoki \\
\hline $\begin{array}{l}\text { Reduced phosphorus leakage from } \\
\text { spreading of manure }\end{array}$ & Fertilizer operation parameter in.mgt files & $\begin{array}{l}\mathrm{BAU}+\mathrm{RBMP}, \\
\mathrm{BAU}+\mathrm{RBMP}+\operatorname{targ}\end{array}$ & $\begin{array}{l}\text { Fyrisån, Vantaanjoki, } \\
\text { Słupia }\end{array}$ \\
\hline Stormwater ponds in urban areas & Pond parameters in.pnd files & $\begin{array}{l}\mathrm{BAU}+\mathrm{RBMP} \\
\mathrm{BAU}+\mathrm{RBMP}+\operatorname{targ}\end{array}$ & Fyrisån, Słupia \\
\hline WWTPs modernization/extension & $\begin{array}{l}\text { Nutrient load values in point source files } \\
\text { representing WWTPs }\end{array}$ & $\mathrm{BAU}+\mathrm{RBMP}$ & Słupia \\
\hline Constructing new on-site WWTPs & $\begin{array}{l}\text { Nutrient load values in point source files } \\
\text { representing on-site WWTPs }\end{array}$ & $\mathrm{BAU}+\mathrm{RBMP}$ & Słupia \\
\hline Constructing new septic tanks & $\begin{array}{l}\text { Nutrient load values in point source files } \\
\text { representing septic tanks }\end{array}$ & $\mathrm{BAU}+\mathrm{RBMP}$ & Słupia \\
\hline
\end{tabular}

BAU Business-As-Usual, RBMP River Basin Management Plans, targ targeted measures, WWTPS Wastewater Treatment Plants 


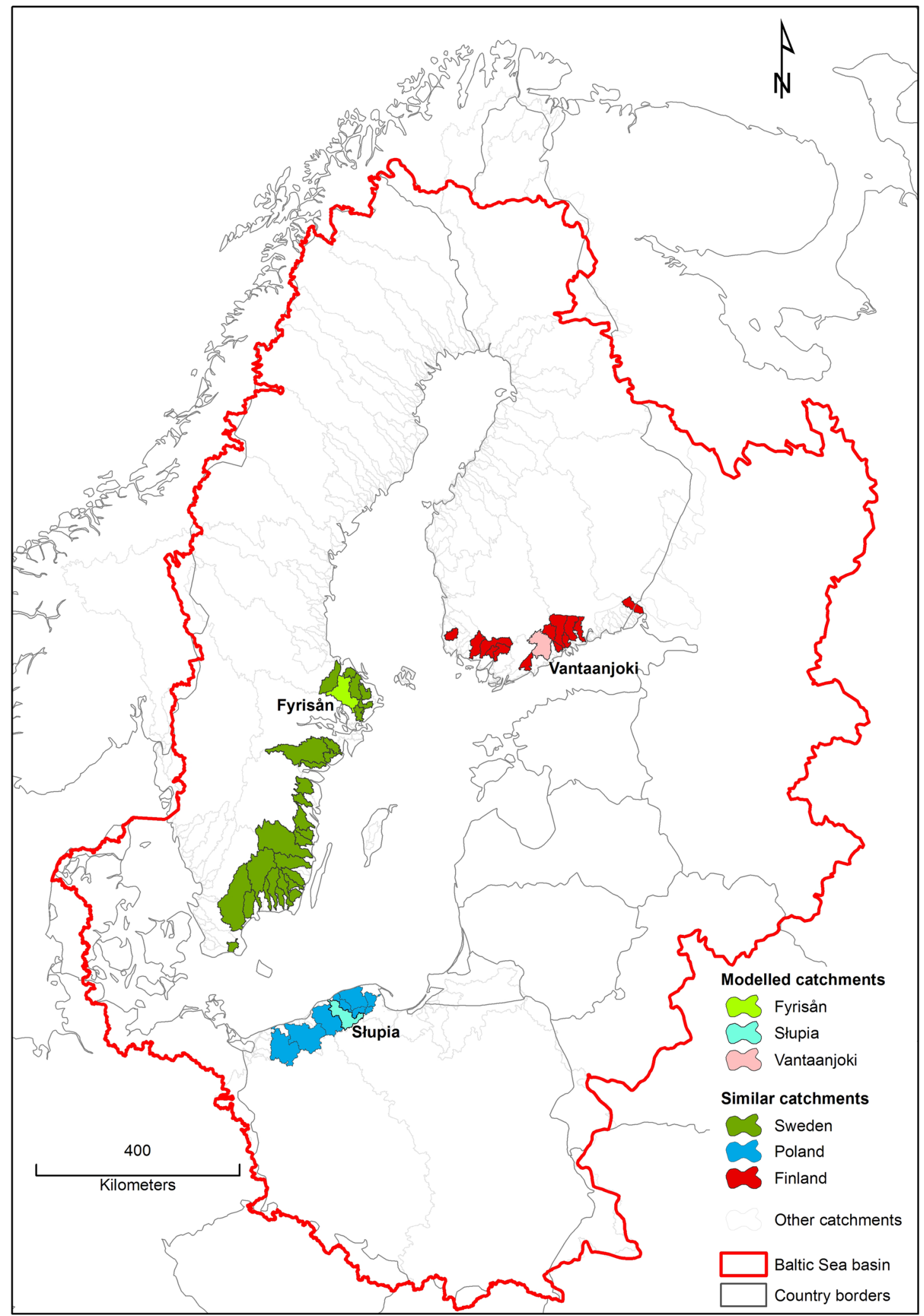

Fig. 2 Location of the identified coastal catchments that are 'similar' to three catchments modelled in this study 
Table 3 Kling-Gupta (KGE, Gupta et al. 2009) goodness-of-fit numbers for SWAT calibration and validation for the observed values of sediment (TSS), total phosphorus (TP) and total nitrogen (TN) loading. The optimal KGE value is 1

\begin{tabular}{llllr}
\hline Catchment & Period & Flow* & TSS & TP \\
\hline Vantaanjoki** & Calibration 2011-2013 & 0.88 & 0.79 & 0.83 \\
\multirow{3}{*}{ Fyrisån } & Validation 2014-2016 & 0.86 & 0.73 & 0.76 \\
& Calibration 2001-2007 & $0.88 / 0.74$ & 0.65 & 0.69 \\
Słupia & Validation 2008-2016 & $0.83 / 0.66$ & 0.63 & 0.62 \\
& Calibration 2000-2007 & 0.76 & 0.55 & 0.45 \\
& Validation 2010-2015 & 0.85 & $-* * *$ & 0.75 \\
\end{tabular}

*Vantaanjoki calibration period 2003-2008 and validation period 2009-2016, Słupia calibration period 2001-2006 and validation period 2007-2016, Fyrisån calibration period 2001-2007 and validation period 2008-2015. Fyrisån KGE values represent northern/eastern parts of the catchment

**Load calibration/validation against continuous data (see Piniewski et al. 2019)

***Validation for TSS was not performed due to missing data

periods (Fig. 3). For Fyrisån the KGE values for total nitrogen (TN) and total phosphorus (TP) were slightly lower than for Vantaanjoki, but still good or satisfactory. As presented in Fig. 3, the variability of nutrient loads was incomparably lower than for Vantaanjoki, potentially resulting from two aspects: (1) scarce observational data set that did not capture many peak events; (2) more flashy character of Vantaanjoki. In Słupia, the KGE values of calibration can be assessed as good for TN and satisfactory for TP and TSS. The validation results for TP, however, are relatively low. It should be noted that for Słupia, calibration and validation were performed only for monthly data. The temporal variability of monthly loads in Słupia was incomparably lower than that of the daily loads in Vantaanjoki, and even in Fyrisån. This can be explained by the difference in time scale, as well as stable flow regime related to the buffering effect of lakes and permeable soils (Fig. 3). Significantly lower model performance for TP compared to TN in Polish conditions was also reported by other authors (Ostojski et al., 2014; Marcinkowski et al., 2013). Despite low correlation between simulated and observed monthly TP loads, the long-term mean load was accurately captured in Słupia, with most observations included in the $95 \%$ prediction uncertainty band (Fig. 3).

The resulting modelled baseline nutrient loads for the case study catchments are as follows: 0.31, 0.18, and $0.44 \mathrm{~kg} \mathrm{P} \mathrm{ha}^{-1}$ year $^{-1}$ and $6.8,7.0$, and $7.8 \mathrm{~kg} \mathrm{~N}^{-1-}$ year $^{-1}$ for Vantaanjoki, Fyrisån, and Słupia, respectively. The results suggest that the highest share of agriculture in Słupia is reflected by the highest specific nutrient load. The difference between Vantaanjoki and Fyrisån regarding TP is in line with the general trend of specific TP load into the Baltic Sea; lower from Sweden than from Finland (HELCOM 2018). The multi-annual variability of nutrient loads is the highest for Vantaanjoki for both TN and TP.

\section{Trends in factors affecting water quality}

Figure 4 presents historical trends for key factors affecting water quality in the analysed catchments. While some factors are observed to undergo rapid changes (e.g. WWTP loads and livestock density), others are subject to small to moderate changes (agricultural area, fertiliser use), or remain fairly stable during the analysed period (land cover). In most cases, the patterns were consistent across catchments, but in some cases, such as $\mathrm{N}$ mineral fertiliser use, small differences occurred (a small increase in $\mathrm{N}$ use in Poland and Sweden compared to a small decrease in Finland). A more detailed discussion about the analysed trends is included in Table S4. For BAU scenario, we used the historical trends presented in Figure 4 as input for developing its assumptions for the SWAT model runs. The trends, if present, were extrapolated into near future. The analysis of RBMPs presented in "Assessment of RBMPs" section allowed for developing assumptions for a scenario called BAU + RBMP. In this scenario, measures were placed randomly without any spatial targeting. In the final step, we developed scenarios (called BAU + RBMP + targ) in which measures were targeted at the areas considered hot spots for $\mathrm{N}$ and $\mathrm{P}$ emission in each catchment. A summary of all scenario assumptions is presented in Table 4.

\section{Model-based assessment of future nutrient loads}

As shown in Fig. 5, only modest changes in TN and TP loads are predicted for BAU scenario for all the analysed catchments. The smallest changes, not exceeding $2 \%$ in absolute values, occur in Fyrisån. The changes for Vantaanjoki and Słupia show two opposite directions for TN and TP. In Słupia, TN loads increase by 5\%, whereas in Vantaanjoki they decrease by $5 \%$. This difference is 

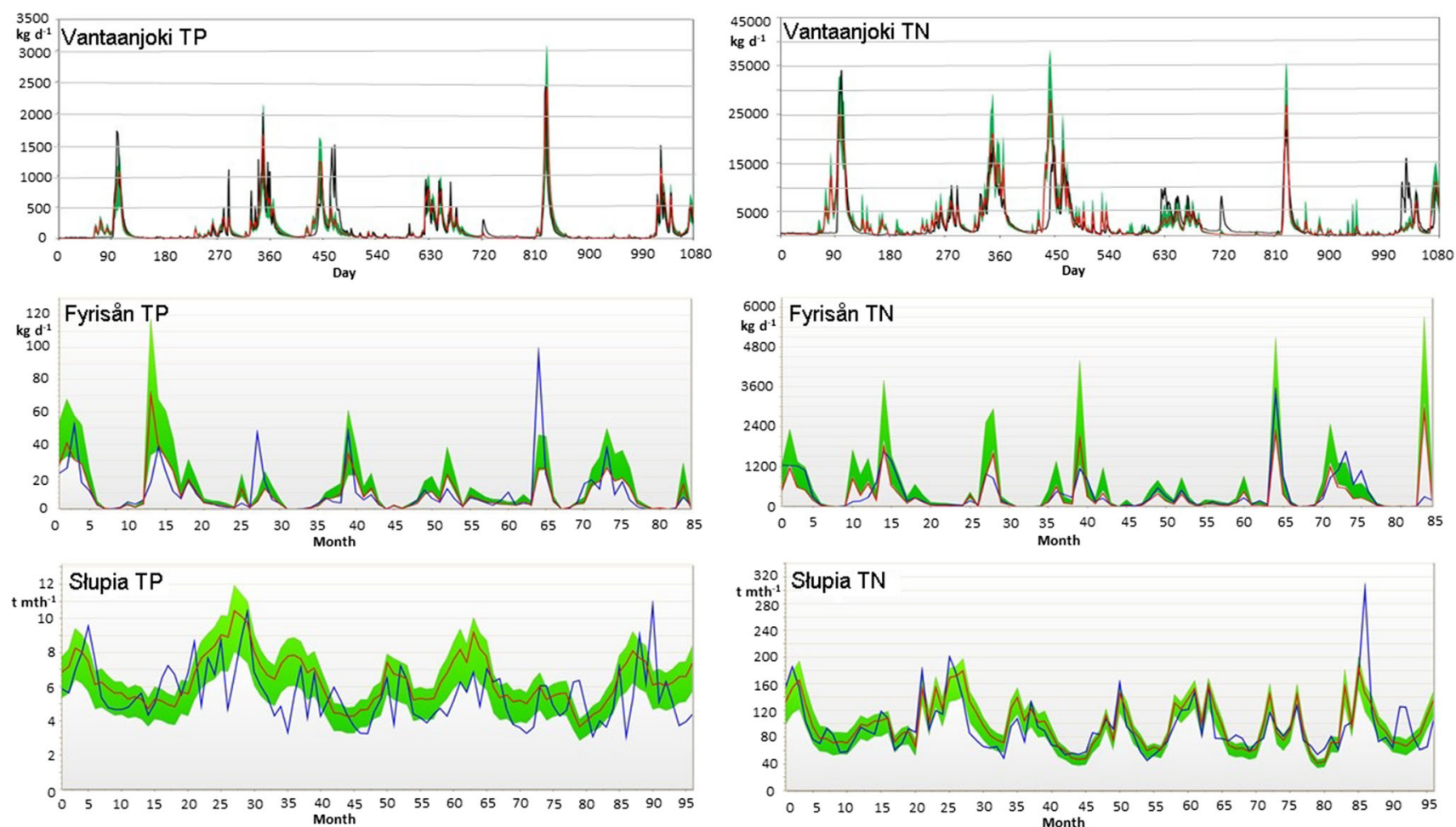

Fig. 3 Modelled (red) and observed (blue) total phosphorus (TP) and total nitrogen (TN) loads $\left(\mathrm{kg} \mathrm{day}^{-1}\right.$, except for Słupia $\mathrm{t}$ month ${ }^{-1}$ ) in the case study catchments for the calibration periods (see Table 3), The green areas describe $95 \%$ prediction uncertainty

primarily caused by a difference in $\mathrm{N}$ fertiliser change (Table 4). For TP loads, a minor increase by $1.5 \%$ is observed for Vantaanjoki, and a decrease by $3.2 \%$ for Stupia. This change is predicted to happen in response to reduced fertiliser rates and TP loads from WWTPs.

BAU + RBMP scenario brings quite different conclusions for each catchment. It has a clearly negligible effect in Slupia (decreases by less than $0.5 \%$ compared to BAU, cf. Figure 5), a moderate effect in Fyrisån (net decreases below 5\%), and a much stronger effect in Vantaanjoki, reaching almost $30 \%$ for TP and $10 \%$ for TN (in comparison to BAU). This is in accordance with the assumptions and scope of this scenario presented in Table 4. Although measures planned in Finnish and Swedish RBMPs were fairly similar, their spatial extent was much greater in Vantaanjoki, resulting in higher effectiveness, particularly for TP. Additional analysis based on decomposition of BAU + RBMP scenario for Vantaanjoki pointed to wintertime vegetation cover on fields as the most effective measure that contributed the most to the overall "success" of RBMP (Fig. S1).

It is noteworthy that while changes in nutrient loads were highly variable across catchments for BAU + RBMP scenario, they were much more homogenous for BAU + RBMP + targ scenario. Targeting of measures was effective in each catchment, further decreasing the reduction of $\mathrm{TN}$ and TP loads by several percent. In Vantaanjoki and
Fyrisån, the additional reductions due to targeting were twice as high for TP than for TN loads, whereas for Słupia net differences were relatively similar for both parameters (7-8\%). It should be emphasised, however, that in the case of $\mathrm{TN}$, the precicted loads for BAU + RBMP were higher than for the Baseline scenario, and targeting contributed to its reduction.

While the results discussed so far represent the stiuation observed at the outlets of three catchments, the spatial patterns within each catchment are also interesting. Figure 6 shows the effectiveness of targeting applied in $\mathrm{BAU}+\mathrm{RBMP}+\operatorname{targ}$ scenario compared with BAU + RBMP scenario for both TN and TP emission at SWAT sub-basin level. Not surprisingly, the "local", sub-basin scale effects of targeted measures can be much higher than the effects simulated at the main outlets. The highest reduction exceeding 50\% was found for TP in several subbasins of the Vantaanjoki catchment. More detailed maps, also presenting mean annual loads generated in both scenarios as well as reductions expressed in absolute terms $\left(\mathrm{kg} \mathrm{ha}^{-1}\right.$ year $\left.^{-1}\right)$, are included in Figs. S2-S7.

\section{DISCUSSION}

Our modelling results show high variability across three BSR catchments, nutrients, and proposed scenarios. First, 

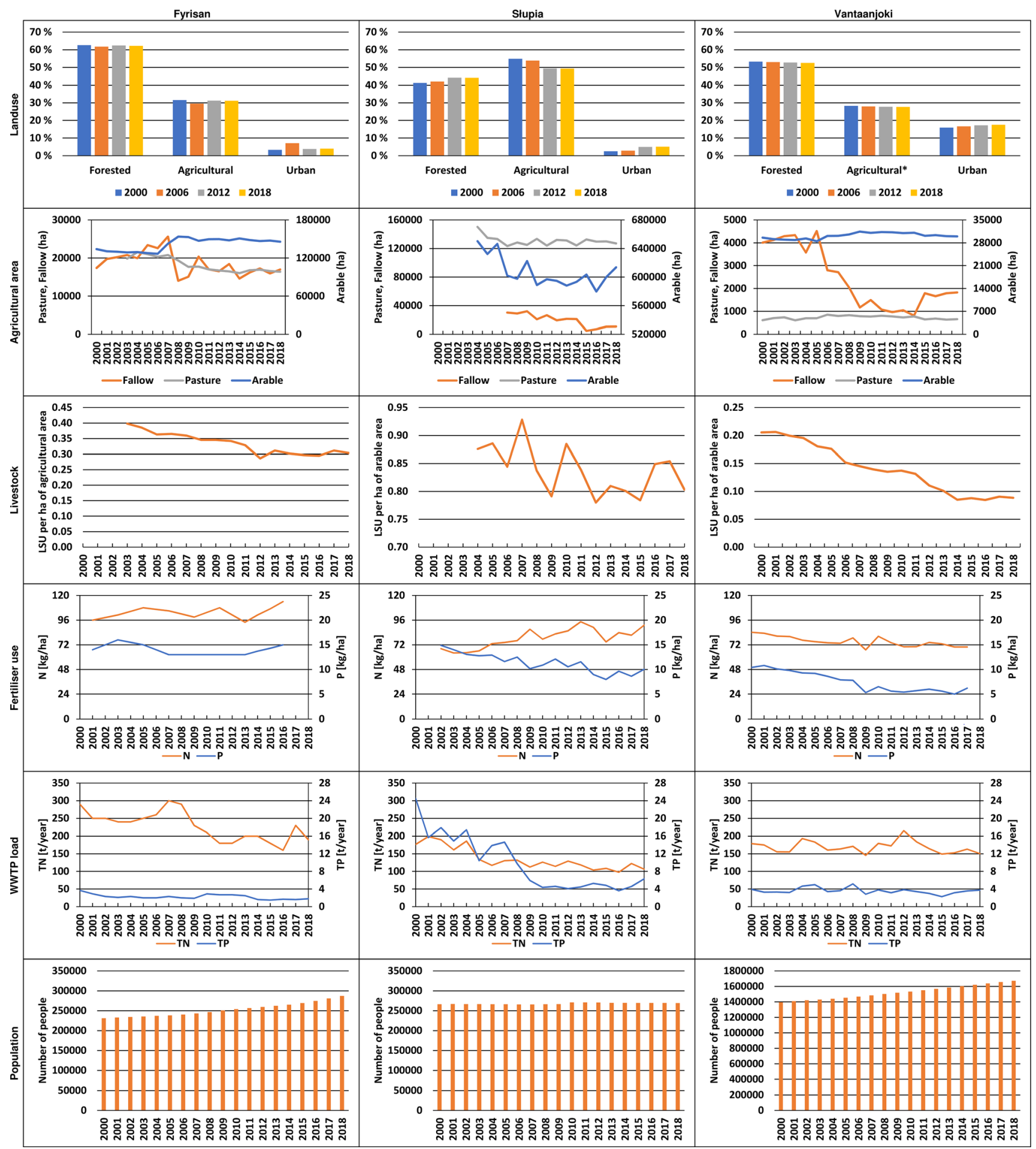

Fig. 4 Historical trends in selected key factors in studied catchments

BAU scenario based on extrapolation of the existing socioeconomic trends did not affect the modelled nutrient loads by more than $5 \%$ in terms of absolute values. This suggests that the impact of ongoing development remains relatively limited, and the system response could be expected to be more intensive due to management measures. The effectiveness of the existing RBMPs in nutrient load reduction, however, considerably varies across catchments. The boldest plans in terms of the spatial extent of measures seem to exist in Finland. If implemented, they would lead to a considerable reduction of TN (15\%) and TP (28\%) loads to the Gulf of Finland compared to the baseline. 
Table 4 Assumptions for the BAU scenario based on the analysis of historical trends and RBMPs for each catchment

\begin{tabular}{|c|c|c|c|c|c|c|}
\hline \multirow[t]{2}{*}{ Catchment } & \multicolumn{2}{|c|}{ Scenario BAU } & \multicolumn{2}{|l|}{ Scenario BAU + RBMP } & \multicolumn{2}{|c|}{ Scenario BAU + RBMP + targeting } \\
\hline & Factor & Extent & Measure & Extent & Measure & Extent \\
\hline \multirow[t]{4}{*}{ Vantaanjoki } & $\begin{array}{l}\text { Land cover } \\
\text { changes }\end{array}$ & $\begin{array}{l}\text { Urban }+3 \% \\
\text { Forest }-1 \% \\
\text { Pasture }-2 \%\end{array}$ & Buffer zones & 360 ha & Buffer zones & Targeted \\
\hline & Fertilizers & $\begin{array}{l}\text { Mineral N }-10 \% \\
\text { Mineral P }-40 \% \\
\text { Manure } 40 \%\end{array}$ & Constructed wetlands & 36 pcs. & Constructed wetlands & Targeted \\
\hline & $\begin{array}{l}\text { Nutrient } \\
\text { loads } \\
\text { from } \\
\text { WWTPs }\end{array}$ & $\mathrm{TN}-10 \% ; \mathrm{TP}-20 \%$ & $\begin{array}{l}\text { Wintertime vegetation cover of } \\
\text { fields ( } 70 \% \text { winter stubble; } 30 \% \\
\text { direct sowing) }\end{array}$ & 13500 ha & $\begin{array}{l}\text { Wintertime vegetation } \\
\text { cover of fields }\end{array}$ & Targeted \\
\hline & & & Perennial grass cultivation & 4824 ha & & \\
\hline \multirow[t]{4}{*}{ Fyrisån } & $\begin{array}{l}\text { Land cover } \\
\text { changes }\end{array}$ & $\begin{array}{l}\text { Urban }+\mathrm{T} 1 \% \\
\text { Fallow land }-1 \%\end{array}$ & Buffer zones & 55 ha & Buffer zones & Targeted \\
\hline & Fertilizers & $\begin{array}{l}\text { Mineral N }+10 \% \\
\text { Mineral P 0\%; } \\
\text { Manure - 20\% }\end{array}$ & Constructed wetlands & 50 ha & Constructed wetlands & Ttargeted \\
\hline & $\begin{array}{l}\text { Nutrient } \\
\text { loads } \\
\text { from } \\
\text { WWTPs }\end{array}$ & TN -20\%; TP- $25 \%$ & $\begin{array}{l}\text { Reduced phosphorus leakage from } \\
\text { spreading of manure }\end{array}$ & $\begin{array}{l}\text { Manure } \\
\text { application } \\
\text { areas }\end{array}$ & & \\
\hline & & & Stormwater ponds in urban areas & 25 ha & $\begin{array}{l}\text { Stormwater ponds in } \\
\text { urban areas }\end{array}$ & \\
\hline \multirow[t]{4}{*}{ Słupia } & $\begin{array}{l}\text { Land cover } \\
\text { changes }\end{array}$ & $\begin{array}{l}\text { Forest }+3 \% \\
\text { Fallow land }-3 \%\end{array}$ & WWTPs modernization/extension & 5 pcs. & $\begin{array}{l}\text { Wintertime vegetation } \\
\text { cover of fields }\end{array}$ & Targeted \\
\hline & Fertilizers & $\begin{array}{l}\text { Mineral } \mathrm{N}+25 \% \\
\text { Mineral } \mathrm{P}-30 \% \\
\text { Manure }-15 \%\end{array}$ & Constructing new on-site WWTPs & 1104 pcs. & $\begin{array}{l}\text { Reduced phosphorus } \\
\text { leakage from } \\
\text { spreading of manure }\end{array}$ & $\begin{array}{l}\text { Manure } \\
\text { application } \\
\text { areas }\end{array}$ \\
\hline & $\begin{array}{l}\text { Nutrient } \\
\text { loads } \\
\text { from } \\
\text { WWTPs }\end{array}$ & TN $-20 \% ;$ TP-35\% & Constructing new septic tanks & 340 pcs. & $\begin{array}{l}\text { Slowing down } \\
\text { emissions from } \\
\text { drainage systems }\end{array}$ & Targeted \\
\hline & & & & & $\begin{array}{l}\text { Stormwater ponds in } \\
\text { urban areas }\end{array}$ & \\
\hline
\end{tabular}

While the set of measures proposed in Swedish plans is partly similar to that in the Finnish ones, their spatial extent is much more modest, resulting in significantly lower reductions. The situation in Poland is different. The current RBMP only covers measures affecting the wastewater sector, and as shown in this study, their effect is almost negligible. Agricultural measures are clearly missing in this plan-point sources from WWTPs constitute only approximately $11 \%$ of TN and TP loads in the Stupia catchment (Koskiaho et al. 2020). On the other hand, a large part of Poland, a country in which about $40 \%$ of total agricultural land of the Baltic Sea catchment is located, is characterised by high $\mathrm{P}$ surpluses that are linked to high livestock densities (in Poland especially pig farms; Svanbäck et al. 2019), as well as low P use efficiency compared to other BSR countries except Russia and Belarus (McCrackin et al. 2018). This suggests that counteracting separation of crop and livestock production as well as improving manure use efficiency could be useful measures aimed at achieving nutrient reduction targets. This would, however, require a closer integration of the WFD and CAP (Common Agricultural Policy), which remains a challenge due to the fact that, monitoring and evaluation systems of CAP are of limited use from the water management perspective and there does not exist any other information system that could provide data required for linking agricultural practices with water quantity and quality (European Court of Auditors 2014). Lack of integration of the WFD and CAP is particularly noticeable in countries with a large share of agricultural land, such as Poland. Further 
A. TN - Vantaanjoki

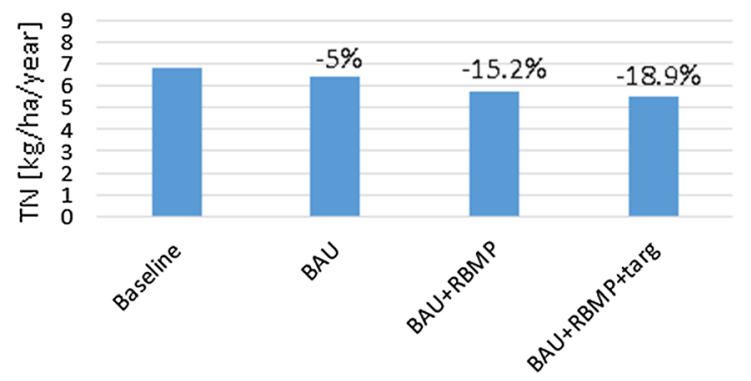

C. TN - Fyrisån

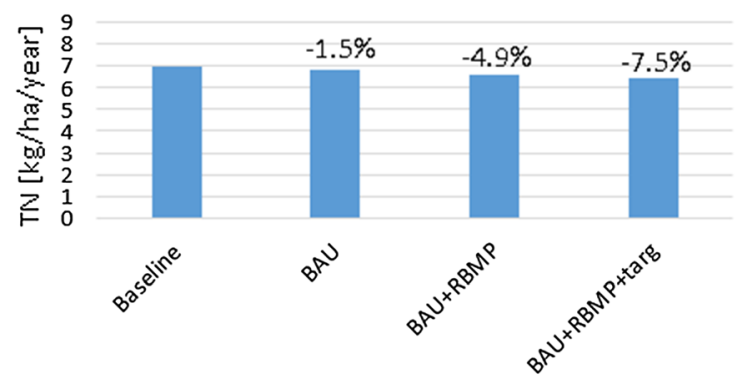

E. TN - Slupia

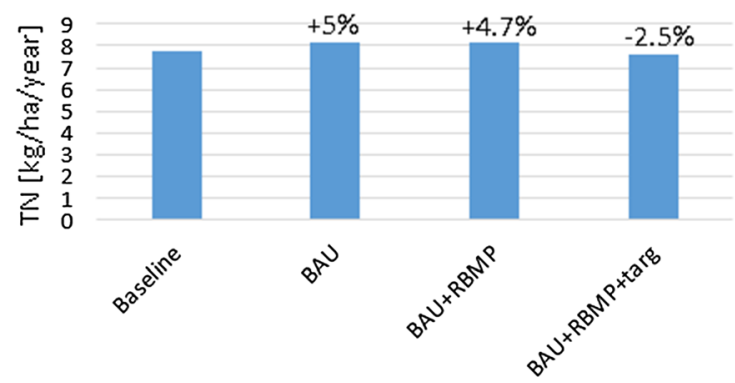

B. TP - Vantaanjoki

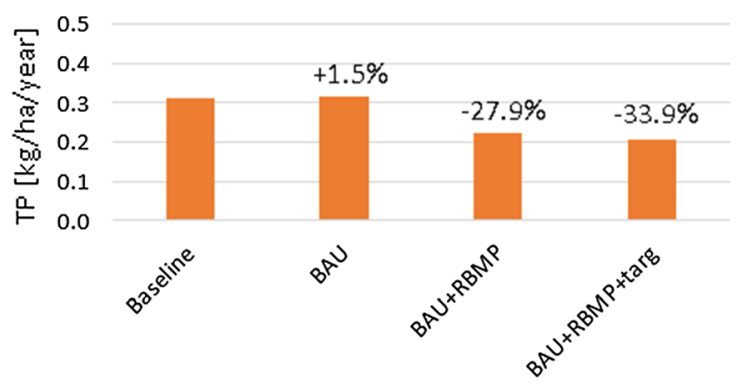

D. TP - Fyrisån

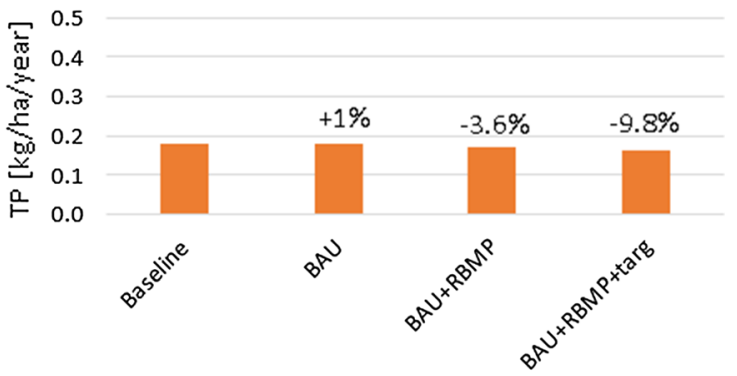

F. TP - Slupia

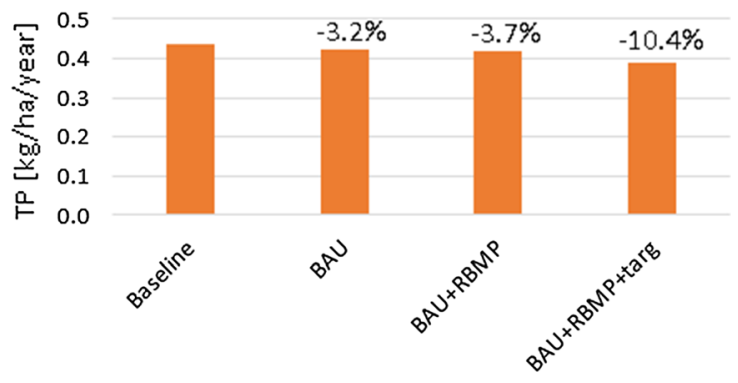

Fig. 5 Mean annual area-specific loads of TN and TP from case study catchments in different scenarios

progress in this respect can be achieved through consistent modelling of the effect of agriculture on water resources, as carried out in this study.

Adding spatially targeted measures to the existing RBMPs would considerably improve their effectiveness in all three catchments for both TN and TP. This is an important outcome that should encourage a wider adoption of targeted measures. Similar implications for TP were drawn in Finland by Puustinen et al. (2019). Simulated reductions, however, should be analysed in a wider context of HELCOM CARTs, as well as reduction targets imposed by the WFD (not existing in Poland-cf. Table 1). Despite a clear spatial discrepancy between country-scale reduction targets and medium-sized catchment scale in this study, our analysis showed that the selected catchments can be considered representative of much larger areas (cf. Figure 2). Assuming the binding character of the country-scale targets in the analysed catchments, it seems that under BAU + $\mathrm{RBMP}+\operatorname{targ}$ scenario they can be achieved in
Vantaanjoki for both TN and TP, and in Fyrisån for TN. They are unlikely to be achieved in Fyrisån for TP, or in Słupia for either TN or TP. It should be emphasised that in the latter case, the gap between the simulated and desired (CART) reduction is vast for TP: $10 \%$ vs. $61 \%$. This points to the questionable feasibility of reduction targets for Poland pointed out in other studies (Pastuszak et al. 2018).

As all modelling studies, also this study has some limitations worth discussing. Not all measures proposed in RBMPs can be modelled with SWAT. Some of the measures are vaguely expressed and/or not quantifiable. In Finland, for example, the RBMP included measures entitled "Land application of slurry and enhanced reduction of nutrient load" and "Agri-environmental guidance" which we did not include in this study. "Structural liming" focused on the improvement of clayey soil structure, proposed in the Swedish RBMP, could also not be modelled.

According to the model simulation by Puustinen et al. (2019), measures implemented in the current RBMP period 


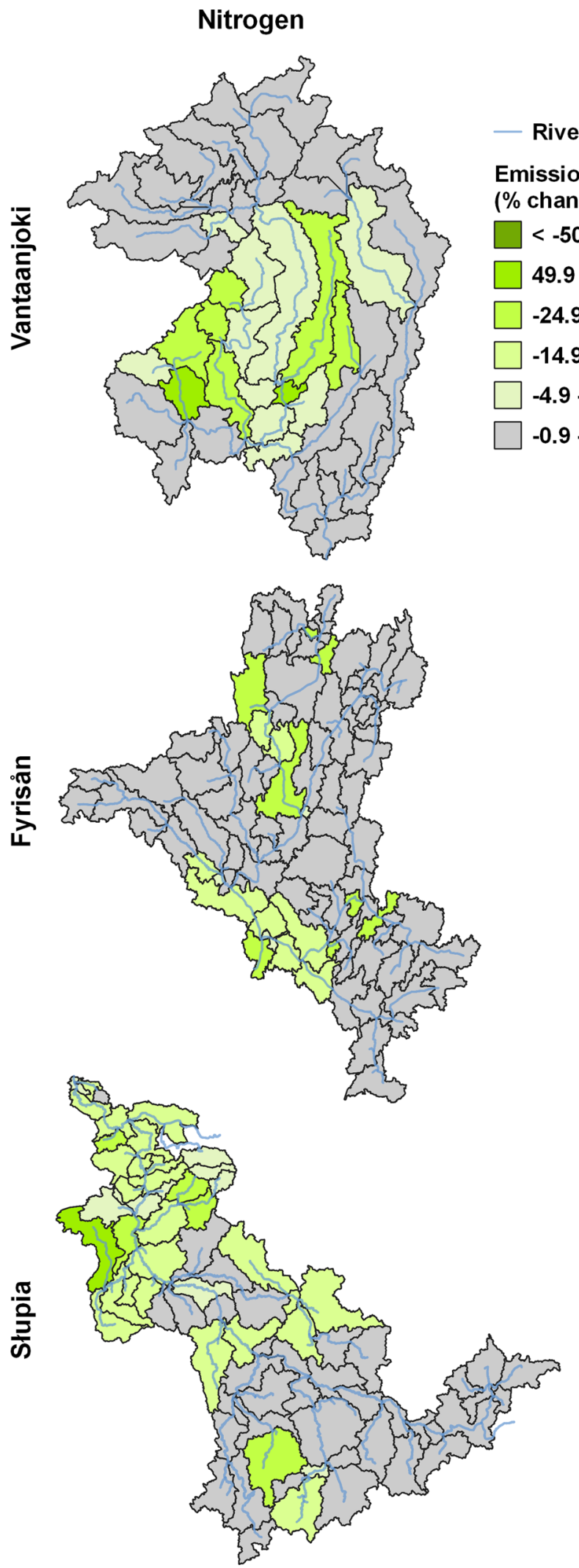

\section{Phosphorus}
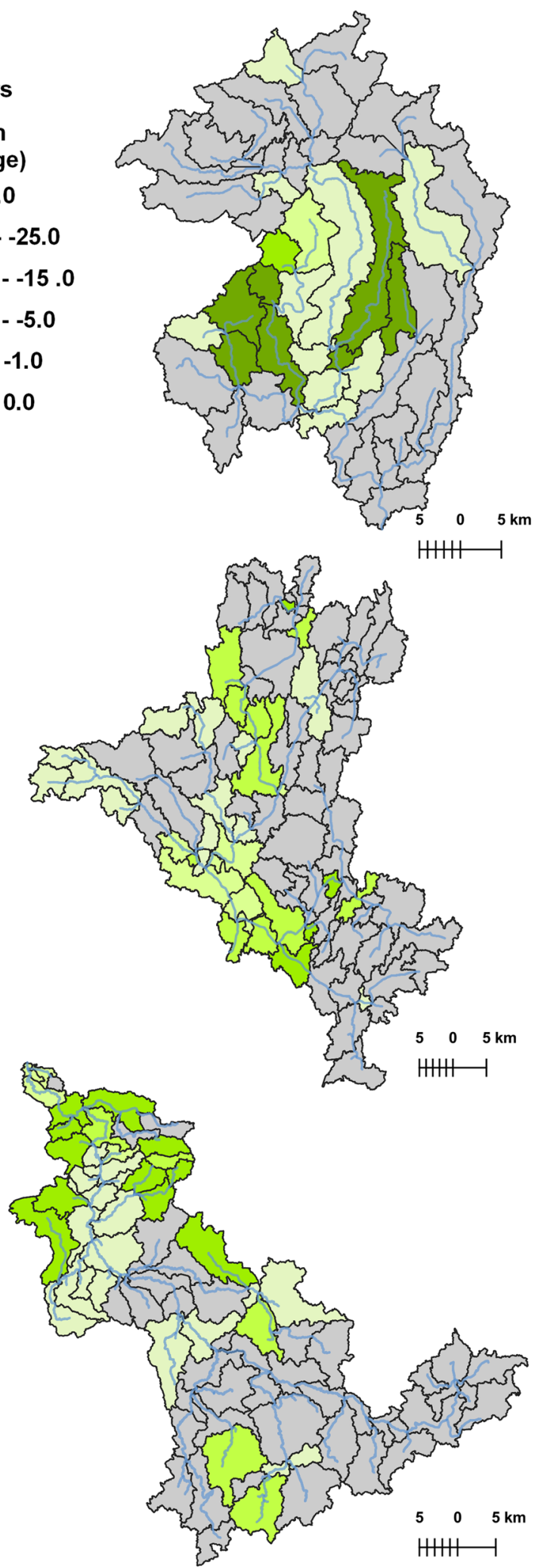

Fig. 6 Average percent decrease in TN and TP emission in BAU + RBMP + targ scenario as compared to BAU + RBMP scenario at subbasin level for three analysed catchments 
(2016-2021) have reduced the erosion of agricultural land by $17 \%$ and load of particulate P by $13 \%$ in Finland. As the winter time stubble, lighter tillage, and direct sowing area expanded, the leaching of dissolved reactive $\mathrm{P}$ (DRP) increased by $7 \%$ from its initial level. Due to this, the TP load reduction remains at $5 \%$. As the area ploughed in autumn was halved, the calculated load of TN decreased by $13 \%$. The possible reduction in the use of fertilisers was not taken into account in the simulation (Puustinen et al. 2019). It was found that leaching of DRP can be so high, e.g. as a result of the release of DRP from plant waste (e.g. Djodjic et al. 2000), that despite the reduced erosion, leaching of TP is increased (Uusitalo et al. 2018). No-till decreased TP losses by $27 \%$ compared with traditional autumn ploughing, corresponding well with the SWAT results of this study for the Vantaanjoki. At the same time, no-till increased DRP loss to an extent where particulate phosphorus (PP) loss decreased by even 54\%. In this study, scenario BAU + RBMP brought a strong effect in Vantaanjoki, reaching almost $30 \%$ for $\mathrm{TP}$ and $10 \%$ for $\mathrm{TN}$. Nitrogen and particle bound $\mathrm{P}$ is in line with previous national studies, but for TP, SWAT seems to overestimate the effect of the measures. This discrepancy could be partly explained by the fact that SWAT does not take into account the increase in soluble phosphorus caused by winter time vegetation cover.

This study focused on the mid-term future horizon reaching 15 years ahead and several factors undoubtedly affecting water resources in the BSR, but neglected the associated impacts of climate warming. This is primarily due to the assumption that such a short time horizon permits prioritising driving forces other than climate. The majority of recent climate impact studies in the region have been indeed reaching the mid- or end of the century. Despite inevitable uncertainty associated with climate projections, a consistent picture arises from a review of these studies: climate warming is expected to increase nutrient loads across BSR. A large-scale study employing the E-HYPE model (Bartosova et al. 2019) showed a significant increase in both $\mathrm{P}$ and $\mathrm{N}$ loads delivered to the Baltic Sea in response to the projected climate change (ensemble mean change by $14 \%$ and $8 \%$, respectively). Projections based on the Fluxmaster regression model showed a $14 \%$ median increase in total inorganic nitrogen export from Sweden (2061-2090) due to climate change (Teutschbein et al. 2017). An even sharper increase in nitrogen loads in response to changing climate was simulated in different catchments in Poland using SWAT (Piniewski et al. 2014; Marcinkowski et al. 2017) as well as MODFLOW and MT3DMS (Olesen et al. 2019). For P loads, the projected increases were lower in the study of Marcinkowski et al. (2017), whereas in the other study of
Piniewski et al. (2014) they reached 20\% (PO4-P). The conclusion from these studies in the context of the present work is that, in the long run, climate change may jeopardise efforts to cut emissions across the entire BSR.

Water quality modelling involving the analysis of land use change impacts and pollution control measures is typically carried out for small to meso-scale catchments. Reaching the ultimate goal of HELCOM to combat Baltic Sea eutrophication and meeting the WFD objectives of achieving good water status would require scientific output at the national or regional scale. In contrast to the majority of other studies in BSR, our paper involves consistent modelling in three countries, as well as an identification of similar coastal catchments in which the results are likely to be comparable to those obtained in this study. This approach may be adopted in other regions of the world as a means of seeking of geographical areas to which study conclusions could be transferred. Nevertheless, the scale mismatch remains a challenge. One of the possible ways forward was recently sketched for $\mathrm{N}$ reduction by Refsgaard et al. (2019), who advocated the concurrent use of small-scale, physically-based models and process-based models operational at macro-scale within a spatially differentiated regulation framework. Another future pathway involves optimization-based targeting permitting valuation of trade-offs between water quality and agricultural production (Bostian et al. 2015).

\section{CONCLUSIONS}

Our model-based evaluation of policy and management in three countries in the BSR permits drawing the following conclusions:

(1) We observe relative stability or a slight decrease in major triggers for nutrients emission over the last 15 years, with the most considerable changes in the Polish catchment, and an evident shift towards an increase in its urban areas and population. Assuming similar trends for the next 15 years (BAU), no significant decrease in $\mathrm{N}$ and $\mathrm{P}$ loads form mediumsized catchments can be expected.

(2) We observe an evident positive impact of the planned WFD measures on a decrease in loads from the analysed catchments, particularly for P. The highest decrease is predicted for Finland and Sweden, and lowest for Poland due to the lack of agricultural measures in RBMPs.

(3) Targeting of measures is expected to bring additional reduction of nutrient loads in all catchments, suggesting that it should be adopted more widely in the Baltic Sea countries. 
(4) In an attempt to upscale the above study findings, we identified 28 Swedish coastal catchments covering an area of $32000 \mathrm{~km}^{2}$ similar to Fyrisån, 12 Finnish coastal catchments covering an area of $8200 \mathrm{~km}^{2}$ similar to Vantaanjoki, and six Polish coastal catchments covering an area of $11000 \mathrm{~km}^{2}$ similar to Słupia. This step from a 'case study' scale towards a regional scale, within the coastal zone of three BSR countries, is particularly relevant from the policy perspective.

(5) Our assessment of the River Basin Management Plans shows that agricultural measures were numerous in Sweden and Finland and missing only in Poland. This, together with promising results of the 'targeting scenario', calls for a stronger integration of the WFD and CAP, which is a prerequisite for mitigating harmful impact of agriculture on the status of rivers and the Baltic Sea.

\begin{abstract}
Acknowledgements This work is a part of the BONUS RETURN project (www.bonusreturn.eu). BONUS RETURN project is supported by BONUS (Art 185), funded jointly by the EU and Swedish Foundation for Strategic Environmental Research FORMAS, Sweden's innovation agency VINNOVA, Academy of Finland and National Centre for Research and Development in Poland. We thank the BONUS Secretariat for their generous funding. We thank two anonymous reviewers for their insightful comments that helped to improve the manuscript.
\end{abstract}

Open Access This article is licensed under a Creative Commons Attribution 4.0 International License, which permits use, sharing, adaptation, distribution and reproduction in any medium or format, as long as you give appropriate credit to the original author(s) and the source, provide a link to the Creative Commons licence, and indicate if changes were made. The images or other third party material in this article are included in the article's Creative Commons licence, unless indicated otherwise in a credit line to the material. If material is not included in the article's Creative Commons licence and your intended use is not permitted by statutory regulation or exceeds the permitted use, you will need to obtain permission directly from the copyright holder. To view a copy of this licence, visit http://creativecommons. org/licenses/by/4.0/.

\section{REFERENCES}

Abbaspour, K.C., C.A. Johnson, and MTh van Genuchten. 2004. Estimating uncertain flow and transport parameters using a sequential uncertainty fitting procedure. Vadose Zone Journal 3: 1340-1352. https://doi.org/10.2136/vzj2004.1340.

Andersen, H.E., G. Blicher-Mathiesen, H. Thodsen, P.M. Andersen, S.E. Larsen, P. Stålnacke, C. Humborg, C.M. Mörth, et al. 2016. Identifying hot spots of agricultural nitrogen loss within the Baltic Sea drainage basin. Water, Air, and Soil pollution 227: 38. https://doi.org/10.1007/s11270-015-2733-7.

Arheimer, B., and B.C. Pers. 2017. Lessons learned? Effects of nutrient reductions from constructing wetlands in 1996-2006 across Sweden. Ecological Engineering 103: 404-414.
Arnold, J.G., R. Srinivasan, R.S. Muttiah, and J.R. Williams. 1998. Large area hydrologic modeling and assessment part I: Model development. JAWRA Journal of the American Water Resources Association 34: 73-89. https://doi.org/10.1111/j.1752-1688. 1998.tb05961.x.

Bartosova, A., R. Capell, J.E. Olesen, M. Jabloun, J.C. Refsgaard, C. Donnelly, K. Hyytiäinen, S. Pihlainen, et al. 2019. Future socioeconomic conditions may have a larger impact than climate change on nutrient loads to the Baltic Sea. Ambio 48: 1325-1336. https://doi.org/10.1007/s13280-019-01243-5

Beck, H.E., N.E. Zimmermann, T.R. McVicar, N. Vergopolan, A. Berg, and E.F. Wood. 2018. Present and future Köppen-Geiger climate classification maps at 1-km resolution. Scientific Data 5: 180214. https://doi.org/10.1038/sdata.2018.214.

Bohman, M. 2018. Lessons from the regulatory approaches to combat eutrophication in the Baltic Sea region. Marine Policy 98: 227-236. https://doi.org/10.1016/j.marpol.2018.09.011.

Bostian, M., G. Whittaker, B. Barnhart, R. Färe, and S. Grosskopf. 2015. Valuing water quality tradeoffs at different spatial scales: An integrated approach using bilevel optimization. Water Resources and Economics. 11: 1-12. https://doi.org/10.1016/j. wre.2015.06.002.

Djodjic, F., and H. Markensten. 2019. From single fields to river basins: Identification of critical source areas for erosion and phosphorus losses at high resolution. Ambio 48: 1129-1142. https://doi.org/10.1007/s13280-018-1134-8.

Djodjic, F., B. Ulén, and L. Bergström. 2000. Temporal and spatial variations of phosphorus losses and drainage in a structured clay soil. Water Research 34: 1687-1695. https://doi.org/10.1016/ S0043-1354(99)00312-7.

Doody, D.G., M. Archbold, R.H. Foy, and R. Flynn. 2012. Approaches to the implementation of the Water Framework Directive: Targeting mitigation measures at critical source areas of diffuse phosphorus in Irish catchments. Journal of Environmental Management 93: 225-234. https://doi.org/10.1016/j. jenvman.2011.09.002.

European Court of Auditors. 2014. Integration of EU Water Policy Objectives with the CAP: A Partial Success. Luxembourg: Special Report European Court of Auditors.

Gupta, H.V., H. Kling, K.K. Yilmaz, and G.F. Martinez. 2009. Decomposition of the mean squared error and NSE performance criteria: Implications for improving hydrological modelling. Journal of Hydrology 377: 80-91. https://doi.org/10.1016/j. jhydrol.2009.08.003.

He, Y., A. Bardossy, and E. Zehe. 2011. A review of regionalisation for continuous streamflow simulation. Hydrology and Earth System Sciences 15: 3539-3553. https://doi.org/10.5194/hess-15-3539-2011.

HELCOM, 2007. HELCOM Baltic Sea Action Plan (adopted by the HELCOM Ministerial meeting, Krakow, Poland 15th November 2007).

HELCOM, 2013. HELCOM Copenhagen Ministerial Declaration. Taking Further Action to Implement the Baltic Sea Action Plan Reaching Good Environmental Status for a Healthy Baltic Sea. 3 October 2013, Copenhagen, Denmark.

HELCOM, 2018. Sources and pathways of nutrients to the Baltic Sea. Baltic Sea Environment Proceedings No. 153. 48 p. ISSN 0357-2994.

Hesse, C., V. Krysanova, A. Stefanova, M. Bielecka, and D.A. Domnin. 2015. Assessment of climate change impacts on water quantity and quality of the multi-river Vistula Lagoon catchment. Hydrological Sciences Journal 60: 890-911. https://doi. org/10.1080/02626667.2014.967247.

Huttunen, I., H. Lehtonen, M. Huttunen, V. Piirainen, M. Korppoo, N. Veijalainen, M. Viitasalo, and B. Vehviläinen. 2015. Effects of climate change and agricultural adaptation on nutrient loading from Finnish catchments to the Baltic Sea. Science of the Total 
Environment 529: 168-181. https://doi.org/10.1016/j.scitotenv. 2015.05.055.

Knuuttila, S., A. Räike, P. Ekholm, and S. Kondratyev. 2017. Nutrient inputs into the Gulf of Finland: Trends and water protection targets. Journal of Marine Systems 171: 54-64. https://doi.org/ 10.1016/j.jmarsys.2016.09.008

Konrad, M.T., H.E. Andersen, H. Thodsen, M. Termansen, and B. Hasler. 2014. Cost-efficient reductions in nutrient loads; identifying optimal spatially specific policy measures. Water Resour. Econ. 7: 39-54.

Koskiaho, J., T. Okruszko, T., M. Piniewski, P. Marcinkowski, S. Tattari, S. Johannesdottir, E. Kärrman and M. Kämäri. 2020 Carbon and nutrient recycling ecotechnologies in three Baltic Sea river basins - the effectiveness in nutrient load reduction. Ecohydrology \& Hydrobiology (in press).

Marcinkowski, P., M. Piniewski, I. Kardel, M. Giełczewski, and T. Okruszko. 2013. Modelling of discharge, nitrate and phosphate loads from the Reda catchment to the Puck Lagoon using SWAT. Annals of Warsaw University of Life Sciences 45: 125-141.

Marcinkowski, P., M. Piniewski, I. Kardel, M. Szcześniak, R. Benestad, R. Srinivasan, S. Ignar, and T. Okruszko. 2017. Effect of climate change on hydrology, sediment and nutrient losses in two lowland catchments in Poland. Water 9: 156.

McCrackin, M.L., B.G. Gustafsson, B. Hong, R.W. Howarth, C. Humborg, O.P. Savchuk, A. Svanbäck, and D.P. Swaney. 2018. Opportunities to reduce nutrient inputs to the Baltic Sea by improving manure use efficiency in agriculture. Regional Environmental Change 18: 1843-1854.

McIntyre, N., H. Lee, H. Wheater, A. Young, and T. Wagener. 2005. Ensemble predictions of runoff in ungauged catchments. Water Resources Research 41: W12434. https://doi.org/10.1029/ 2005WR0044289.

Olesen, J.E., C.D. Børgesen, F. Hashemi, M. Jabloun, D. BarMichalczyk, P. Wachniew, A.J. Zurek, A. Bartosova, et al. 2019. Nitrate leaching losses from two Baltic Sea catchments under scenarios of changes in land use, land management and climate. Ambio 48: 1252-1263. https://doi.org/10.1007/s13280-01901254-2.

Ostojski, M.S., J. Niedbała, P. Orlińska-Woźniak, P. Wilk, and J. Gębala. 2014. Soil and water assessment tool model calibration results for different catchment sizes in Poland. Journal of Environmental Quality 43: 132-144.

Pastuszak, M., T. Kowalkowski, J. Kopiński, J. Stalenga, and D. Panasiuk. 2014. Impact of forecasted changes in Polish economy (2015 and 2020) on nutrient emission into the river basins. Science of the Total Environment 493: 32-43. https://doi.org/10. 1016/j.scitotenv.2014.05.124.

Pastuszak, M., A.C. Bryhn, L. Håkanson, P. Stålnacke, M. Zalewski, and T. Wodzinowski. 2018. Reduction of nutrient emission from Polish territory into the Baltic Sea (1988-2014) confronted with real environmental needs and international requirements. Oceanol Hydrobiol Stud 47: 140-166. https://doi.org/10.1515/ ohs-2018-0015.

Piniewski, M., I. Kardel, M. Giełczewski, P. Marcinkowski, and T. Okruszko. 2014. Climate change and agricultural development: Adapting Polish agriculture to reduce future nutrient loads in a coastal watershed. Ambio 43: 644-660. https://doi.org/10.1007/ s13280-013-0461-z.

Piniewski, M., P. Marcinkowski, I. Kardel, M. Giełczewski, K. Izydorczyk, and W. Frątczak. 2015. Spatial quantification of non-point source pollution in a meso-scale catchment for an assessment of buffer zones efficiency. Water 7: 1889-1920. https://doi.org/10.3390/w7051889.

Piniewski, M., M. Szcześniak, I. Kardel, T. Berezewski, T. Okruszko, R. Srinivasan, D. Vikhamar Schuler, and Z.W. Kundzewicz. 2017. Hydrological modelling of the Vistula and Odra river basins using SWAT. Hydrological Sciences Journal. https://doi. org/10.1080/02626667.2017.1321842.

Piniewski, M., P. Marcinkowski, J. Koskiaho, and S. Tattari. 2019. The effect of sampling frequency and strategy on water quality modelling driven by high-frequency monitoring data in a boreal catchment. Journal of Hydrology 579: 124186. https://doi.org/ 10.1016/j.jhydrol.2019.124186.

Puustinen, M., S. Tattari, S. Väisänen, P. Virkajärvi, M. Räty, K. Järvenranta, J. Koskiaho, E. Röman, et al. 2019. Ravinteiden kierrätys alkutuotannossa ja sen vaikutukset vesien tilaanKiertoVesi -hankkeen loppuraportti. Suomen ympäristökeskuksen raportteja 22/2019. Suomen ympäristökeskus, Helsinki. $142 \mathrm{~s}$. Online: https://helda.helsinki.fi/bitstream/handle/10138/304956/ SYKEra_22_2019.pdf.

Refsgaard, J.C., A.L. Hansen, A.L. Højberg, J.E. Olesen, F. Hashemi, P. Wachniew, A. Wörman, A. Bartosova, et al. 2019. Spatially differentiated regulation: Can it save the Baltic Sea from excessive N-loads? Ambio 48: 1278-1289. https://doi.org/10. 1007/s13280-019-01195-w.

Schumacher, T. 2012. Great potential but little impact: The European Union's Protection Policies for the Baltic Sea. Baltic Journal of Political Science. https://doi.org/10.15388/bjps.2012.1.431.

Svanbäck, A., M.L. McCrackin, D.P. Swaney, H. Linefur, B.G. Gustafsson, R.W. Howarth, and C. Humborg. 2019. Reducing agricultural nutrient surpluses in a large catchment-links to livestock density. The Science of the Total Environment 648: $1549-1559$.

Teutschbein, C., R.A. Sponseller, T. Grabs, M. Blackburn, E.W. Boyer, J.K. Hytteborn, and K. Bishop. 2017. Future riverine inorganic nitrogen load to the Baltic Sea from Sweden: An ensemble approach to assessing climate change effects. Global Biogeochemical Cycles 31: 1674-1701.

Thodsen, H., H.E. Andersen, G. Blicher-Mathiesen, and D. Trolle. 2015. The combined effects of fertilizer reduction on high risk areas and increased fertilization on low risk areas, investigated using the SWAT model for a Danish catchment. Acta Agriculturae Scandinavica, Section B 65: 217-227. https://doi.org/10. 1080/09064710.2015.1010564.

Thodsen, H., C. Farkas, J. Chormanski, D. Trolle, G. BlicherMathiesen, R. Grant, A. Engebretsen, I. Kardel, et al. 2017. Modelling nutrient load changes from fertilizer application scenarios in six catchments around the Baltic Sea. Agriculture 7: 41. https://doi.org/10.3390/agriculture7050041.

Uusitalo, R., R. Lemola, and E. Turtola. 2018. Surface and subsurface phosphorus discharge from a clay soil in nine-year study comparing no-till and plowing. Journal of Environmental Quality 47: 1478-1486. https://doi.org/10.2134/jeq2018.06. 0242.

Zhang, Y., and F.H.S. Chiew. 2009. Relative merits of different methods for runoff predicitions in ungauged catchments. Water Resources Research 45: W07412. https://doi.org/10.1029/ 2008W007504.

Publisher's Note Springer Nature remains neutral with regard to jurisdictional claims in published maps and institutional affiliations. 


\section{AUTHOR BIOGRAPHIES}

Mikołaj Piniewski $(\square)$ is an Associate Professor at the Department of Hydrology, Meteorology and Water Management of the Warsaw University of Life Sciences (WULS-SGGW). His research activities focus on hydrological and water quality modelling and impacts of climate and land use change on water resources.

Address: Department of Hydrology, Meteorology and Water Management, Warsaw University of Life Sciences, Nowoursynowska 166, 02-787 Warsaw, Poland.

e-mail: Mikolaj_Piniewski@sggw.edu.pl

Sirkka Tattari is a hydrologist at the Freshwater Centre of the Finnish Environment Institute. Her research activities focus on diffuse load modeling, the evaluation of the effectiveness of water protection methods, and the new continuous measurement of water quality.

Address: Finnish Environment Institute (SYKE), Latokartanonkaari 11, 00790 Helsinki, Finland.

e-mail: sirkka.tattari@ymparisto.fi

Jari Koskiaho is a PhD at the Finnish Environment Institute (SYKE). His research activities focus on watershed modeling and mitigation of nutrient loss from agricultural runoff using various agri-environmental measures.

Address: Finnish Environment Institute (SYKE), Latokartanonkaari 11, 00790 Helsinki, Finland.

e-mail: jari.koskiaho@ymparisto.fi

Olle Olsson is a Senior Research Fellow at the Stockholm Environment Institute, where his research is focused on policy and market issues related to sustainability transitions

Address: Stockholm Environment Institute (SEI), Linnégatan 87D, 10451 Stockholm, Sweden.

e-mail: olle.olsson@sei.org

Faruk Djodjic is an Associate Professor at the Swedish University of Agricultural Sciences. His research interests include mobilisation and transport of nutrients from diffuse sources at different scales.
Address: Swedish University of Agricultural Sciences, Lennart Hjelms väg 9, 75007 Uppsala, Sweden.

e-mail: Faruk.Djodjic@slu.se

Marek Giełczewski is a $\mathrm{PhD}$ at the Department of Hydrology, Meteorology and Water Management of the Warsaw University of Life Sciences (WULS-SGGW). His research activities focus on stakeholders participation and scenario studies in hydrological modelling of catchments.

Address: Department of Hydrology, Meteorology and Water Management, Warsaw University of Life Sciences, Nowoursynowska 166, 02-787 Warsaw, Poland.

e-mail: Marek_Gielczewski@sggw.edu.pl

Pawel Marcinkowski is a $\mathrm{PhD}$ at the Department of Hydrology, Meteorology and Water Management of the Warsaw University of Life Sciences (WULS-SGGW). His research focuses on hydrological and water quality modelling.

Address: Department of Hydrology, Meteorology and Water Management, Warsaw University of Life Sciences, Nowoursynowska 166, 02-787 Warsaw, Poland.

e-mail: Pawel_Marcinkowski@sggw.edu.pl

Marta Księżniak is a PhD student at the Department of Remote Sensing and Environmental Assessment of Warsaw University of Life Sciences (WULS-SGGW). Her research activities focus on hydrological modelling.

Address: Department of Remote Sensing and Environmental Assessment, Warsaw University of Life Sciences, Nowoursynowska 166, 02-787 Warsaw, Poland.

e-mail: Marta_Ksiezniak@sggw.edu.pl

Tomasz Okruszko is a Professor at the Warsaw University of Life Sciences (WULS-SGGW). His research activities focus on water resources management and environmental hydrology.

Address: Department of Hydrology, Meteorology and Water Management, Warsaw University of Life Sciences, Nowoursynowska 166, 02-787 Warsaw, Poland

e-mail: Tomasz_Okruszko@sggw.edu.pl 